\title{
DIAKRONIKA
}

Vol. 19 No. 1 Th. 2019 p: 66-77

ISSN: 1411-1764 (Print) | 2620-9446 (Online)

http://diakronika.ppj.unp.ac.id

\section{Sekolah Menengah Kesenian: Cipta Karakter Pelestari Budaya di Sumatera Barat}

\section{Sri Haryati Putri}

sriharyatiputri05@gmail.com

Universitas Andalas

\begin{abstract}
This study aims to delve deeper into how the role of art in traditional culture can be used as character building for the next generation of the nation. The art school which is specialized in Vocational High Schools (SMK), offers expertise programs to junior high school graduates who are interested in exploring and learning traditional arts and culture. The presence of art-based formal schools, of course, can have a positive impact on the younger generation to maintain and preserve the art of traditional culture as forming a moral character, as well as the emergence of a sense of love for their own culture. Usually Vocational Schools are very identical with technical schools, machinery, and other fields of technology, but art Vocational Schools in West Sumatra, especially the city of Padang, offer different skills than vocational education in general, namely traditional arts. This is evidenced by the presence of Vocational High School 4, Vocational High School 8 and Padang Vocational High School 7, which are art vocational schools in West Sumatra, especially in Padang which make traditional arts and crafts of Minangkabau culture a skill program developed by their students. This school is maintained and is the pride of the people of Padang City.
\end{abstract}

Keywords: Art, Character, Vocational School, Education, Culture, Tradition

\begin{abstract}
Abstrak
Kajian ini bertujuan untuk menggali lebih dalam bagaimana peran seni dalam budaya tradisional dapat dijadikan sebagai pembentukan karakter bagi generasi penerus bangsa. Sekolah seni yang terspesialisasi pada Sekolah Menengah Kejuruan (SMK), menawarkan program keahlian kepada lulusan setingkat SLTP yang berminat untuk menggali serta mempelajari seni dan budaya tradisional. Kehadiran sekolah-sekolah formal berbasis kesenian, tentunya dapat memberikan dampak positif bagi generasi muda untuk tetap mempertahankan dan melestarikan seni budaya tradisi sebagai pembentuk karakter moral, serta timbulnya rasa cinta akan budaya sendiri. Biasanya SMK identik sekali dengan sekolah teknik, mesin, dan dibidang teknologi lainnya, akan tetapi SMK-SMK seni yang ada di Sumatera Barat, khususnya kota Padang, menawarkan keahlian yang berbeda dengan pendidikan SMK pada umumnya, yakni seni tradisi. Hal ini dibuktikan dengan kehadiran SMKN 4, SMKN 8 dan SMKN 7 Padang, merupakan SMK-SMK seni yang ada di Sumatera Barat, khususnya Kota Padang yang menjadikan kesenian tradisi dan kerajinan budaya Minangkabau sebagai program keahlian yang dikembangkan oleh para siswanya. Sekolah ini
\end{abstract}


Sri Haryati Putri

Sekolah Menengah Kesenian: Cipta Karakter Pelestari Budaya di Sumatera Barat

keberadaannya tetap terjaga dan merupakan kebanggaan dari masyarakat Kota Padang.

Kata kunci:Seni, Karakter, SMK, Pendidikan, Budaya, Tradisi

(c) (i) (2) This work is licensed under the Creative Commons Attribution-ShareAlike 4.0 International License.

\section{Pendahuluan}

Mobil Esemka karya anak bangsa, beberapa tahun silam telah membuat heboh khalayak ramai. Betapa tidak, siswa-siswa Sekolah Menengah Kejuruan (SMK) unjuk kebolehan dengan berkarya. Mobil Esemka pertama kali muncul pada tahun 2009 yang dirakit oleh siswa-siswa Sekolah Menengah Kejuruan (SMK). Nama Esemka menjadi lebih eksis dikala Joko Widodo yang pada saat itu masih menjabat sebagai Walikota Solo menjadikan mobil Esemka sebagai kendaraan dinasnya. Selain telah berhasil menembus pasar nasional, digadang-gadang mobil Esemka mampu menjadi alat transportasi kebanggaan Indonesia di antara serbuan produk otomotif buatan asing. Sontak semua masyarakat seantero Indonesia berbangga dan senantiasa mengapresiasi usaha kreatif dari kalangan pelajar ini. Sudah selayaknya capaian siswa-siswa SMK demikian, mereka harus punya keterampilan yang mumpuni sesuai dengan bidang yang dipelajari dibangku sekolah. Saat ini telah menjamur beragam sekolah kejuruan yang menawarkan berbagai keahlian kepada siswanya, tidak hanya dibidang teknik otomotif dan teknologi saja, tetapi juga merambah dunia kuliner, fashion dan kesenian. Sekolah kejuruan dengan basis seni dapat kita jumpai pada kompleks SMK Seni budaya yang ada di Cengkeh Padang Sumatera Barat. Keberadaannya cukup eksis dan berhasil memberikan warna baru terhadap perkembangan seni budaya di Sumatera Barat.

Sekolah-sekolah seni tersebut hadir sebagai salah satu upaya mewujudkan pribadi sadar budaya. Sadar untuk membudayakan manusia, yang dapat dijalankan secara formal, informal, dan non formal (Jazul., 2001). Pendidikan seni dewasa ini, umumnya hanya dapat dipelajari melalui lembaga non formal, bebas dan tidak berada di bawah naungan suatu instansi lembaga pemerintahan tertentu. Sifatnya milik pribadi dan tidak ada aturan formal yang mengikat. Hal ini tergambar pada beragam komunitas-komunitas pencinta seni dan sanggar-sanggar yang mewadahi generasi muda untuk kreatif mengembangkan bakat seni yang dimiliki.

Hanya segelintir dari jenjang pendidikan sekolah formal yang mengembangkan seni sebagai keahlian yang ditawarkan kepada siswanya. 
Terdapat tiga SMK sebagai sekolah formal yang berbasis seni budaya dan seni kerajinan di Sumatera Barat khususnya di Kota Padang, (Hasbullah, 2005) yaitu SMKN 8 Padang, yang berasal dari nama Sekolah Menengah Industri Kerajinan (SMIK), kemudian SMKN 4 Padang yang dikenal dengan Sekolah Menengah Seni Rupa (SMSR), dan SMKN 7 Padang yang masih dikenal dengan nama Sekolah Menengah Karawitan Indonesia (SMKI), tercatat pada tahun 1982 sebagai satu-satunya SMKI yang ada di Sumatera. Terkhusus SMKN 7 Padang, spesifikasi keahlian yang dimiliki oleh siswanya adalah seni tradisi Minangkabau. Sekolah seperti ini digadang-gadangkan hanya ada satu di Sumatera Barat bahkan pulau Sumatera (Padang, 2014).

Kehadiran sekolah-sekolah ini sebagai lembaga formal berbasis kesenian nyatanya masih dipandang sebelah mata. Banyak masyarakat, para orang tua siswa yang menganggap bahwa pelajaran seni bukanlah pelajaran penting. Apalagi bila ditinjau dari segi ekonomi, menjalani hidup dengan menjadi seorang seniman dinilai kurang menjanjikan. Ditambah lagi dengan banyaknya seniman yang punya nama besar, tetapi tetap hidup miskin. Hal ini semakin menguatkan banyak orang tua yang melarang anaknya untuk melanjutkan pendidikan pada sekolah-sekolah SMK Seni tersebut (Purnawati., 2008).

Lesunya berbagai cabang seni budaya pada sekolah formal disebabkan oleh absennya apresiasi masyarakat terhadap seni, terutama terhadap seni budaya tradisi. Diperparah dengan siswa yang melanjutkan pendidikan pada sekolah-sekolah seni tidak diiringi dengan bakat seni yang telah dimiliki. Pilihan kedua dikala tidak diterima pada sekolah negeri. Belajar seni apabila tidak diiringi dengan bakat seni yang telah dimiliki, bagaimanapun cara belajarnya hasilnya tetap tidak akan bagus. Hal ini sudah tidak sejalan dengan titahnya Sekolah Menengah Kejuruan (SMK) yakni jenjang pendidikan yang mempersiapkan anak didik untuk menguasai keahlian-keahlian tertentu. Setiap tamatan SMK bisa langsung terjun ke lapangan dan membuka lapangan pekerjaan sesuai dengan keahlian yang dipelajari dibangku sekolah (Hasbullah, 2005).

Termasuk SMK-SMK berbasis seni budaya dan kerajinan, siswanya harus terampil dengan bidang seni yang ditekuni, maka setelah tamat mereka hadir sebagai seniman-seniman handal yang menspesialisikan seni budaya Minangkabau sebagai keahlian utama. Keahlian dibidang seni terdiri dari seni rupa, seni musik, seni tari dan teater. Dari berbagai ragam jenis seni tersebut, setiap sekolah diberi kebebasan untuk memilih jenis kesenian yang menjadi fokus sekolahnya sesuai dengan budaya setempat. Bidang keahlian di Sekolah Menengah Kejuruan (SMK) yang berbasis seni perlu mendapat apresiasi karena hal itu berarti dukungan terhadap pewarisan seni tradisi 
(Maryetti, 2010). Sumatera Barat dengan keberagaman budaya disetiap daerahnya, telah menjadikan seni budaya dan kerajinan kedalam struktur pendidikan formal (Maryetti, 2010).

Perlu disadari bahwa, pelaksanaan pendidikan di berbagai pusat pendidikan selalu dilandasi cita-cita membentuk manusia ideal. Kekurangan dalam sistem pendidikan dapat terlihat pada kebijakan pendidikan nasional cenderung mengedepankan pendidikan sains dan teknologi sehingga pendidikan seni tampak termajinalkan. Dampak dari kebijakan semacam itu diantaranya adalah muncul krisis moral, budaya, politisasi pendidikan dan mudah timbul kekerasan.

Secara konseptual, manusia ideal salah satunya mempunyai ciri memiliki keseimbangan pertumbuhan jasmani dan rohani yang dicirikan oleh harmoni unsur-unsur cipta, rasa, dan karsa. Semua ini hanya dapat diwujudkan apabila kebudayaan suatu etnis dapat terapresiasi dan didukung oleh berbagai elemen masyarakat (Ahmad, 1976). Pendidikan seni di sekolah adalah bentuk nyata dalam pembentukan karakter bangsa yang berbudaya, cinta budaya lokal, tanah air, tanggung jawab dan nilai-nilai luhur yang dapat digali dari mempelajari suatu cabang kesenian

\section{Pembahasan}

Pada masa Orde Baru, program pemerintah dalam mengambil kebijakan dengan menerapkan Repelita (Rencana Pembangunan Lima Tahun), isinya lebih menitikberatkan pada bidang pendidikan, adanya anggaran besar diperuntukkan pada pendidikan teknik dan kejuruan. Sebagai tindak lanjut dari kebijaksanaan pemerintah digariskan dalam GBHN, maka pemerintah daerah mewujudkannya dengan adanya pembangunan sekolah-sekolah.

Selain dari Repelita I tahun 1969 sampai Repelita II tahun 1973, maka pembangunan sekolah tetap dilanjutkan hingga Repelita IV. Sekolah-sekolah yang didirikan pada umumnya mengarah pada sekolah-sekolah kejuruan atau SMK. Hal ini dibuktikan dengan adanya pembangunan lapangan pekerjaan yang ditujukan untuk memperbanyak mendirikan sekolah-sekolah menengah kejuruan.

Jenis pendidikan kejuruan berdasarkan Undang-Undang Pendidikan Nomor 2 Tahun 1989 diubah menjadi jenis pendidikan SMK (Sekolah Menengah Kejuruan). Pada tahun 2008 berdasarkan Surat Direktur Jendral Manajemen Pendidikan Dasar dan Menengah Nomor 2873/C5.3/MN/2008 mengenai spektrum keahlian pendidikan menengah kejuruan, pemerintah membagi kelompok pendidikan menengah kejuruan menjadi 6 bidang studi keahlian yaitu teknologi rekayasa, teknologi informasi dan komunikasi, 
kesehatan, seni kerajinan, pariwisata, agribisnis dan agroteknologi, serta bisnis dan manajemen (Nasional, 2003).

Secara umum dapat ditemukan bahwa SMK terbagi kedalam beberapa bidang diantaranya Sekolah Kejuruan Teknik, Sekolah Kejuruan Kesejahteraan, Sekolah Kejuruan Ekonomi, Sekolah Kejuruan Kerajinan. Pada masa orde baru, SMK seni kerajinan dan pariwisata ditempatkan oleh Kementerian Pendidikan dan Kebudayaan kedalam beberapa kelompok pendidikan kejuruan di antaranya Sekolah Menengah Kesejahteraan Keluarga (SMKK), Sekolah Teknologi Kerumahtanggaan (SMTK), Sekolah Menengah Industri Kerajinan (SMIK), Sekolah Menengah Seni Rupa (SMSR), Sekolah Menengah Karawitan Indonesia (SMKI), dan Sekolah Menengah Musik (SMM) (Yoeti, 1983).

Masa orde baru ditandai dengan pemerintah Indonesia melakukan pembangunan nasional dalam segala bidang, negara Indonesia berazaskan moral Pancasila. Pembangunan nasional dalam bidang pendidikan tercantum dalam Tap MPR-RI No IV/MPR/1973. Pendidikan kejuruan oleh pemerintah Indonesia diarahkan untuk menghasilkan lulusan sekolah kejuruan yang cinta terhadap tanah air Indonesia dan ikut berpartisipasi dalam pembangunan ekonomi nasional Indonesia. Lulusan pendidikan kejuruan oleh pemerintah Orde Baru disiapkan untuk memasuki dunia kerja dalam bidang industri, pertanian, bisnis, perdagangan, industri rumah tangga, dan kesenian.

Penyelenggaraan pendidikan menengah kejuruan masa orde baru dilaksanakan melalui berbagai sistem yaitu pendidikan luar sekolah (kursuskursus keterampilan, keahlian, dan pelatihan kerja industri), serta melalui pendidikan tinggi profesional. Hingga tahun 2000-an Sekolah Menengah Kejuruan (SMK) telah tersebar di berbagai daerah, SMK ini mengusung program keahlian masing-masing, yang kemudian menjadi identitas dan ciri khas dari sekolah itu sendiri. Propinsi Sumatera Barat dengan etnis Minangkabau, telah menjadikan seni dan budaya tradisi sebagai keahlian yang ditawarkan pada siswanya melalui sekolah kejuruan (Laporan Tahunan Kantor Wilayah Departemen Pendidikan dan Kebudayaan Provinsi Sumatera Barat Tahun 1979/1980, 2018).

Terdapat tiga SMK sekolah formal yang berbasis seni tradisional dan seni kerajinan di Sumatera Barat khususnya Kota Padang, diantaranya jurusan busana butik, teknik kendaraan ringan, teknik komputer jaringan, kriya keramik, kriya logam, kriya kayu, dan kriya tekstil terdapat di SMKN 8 Padang, yang berasal dari nama Sekolah Menengah Industri Kerajinan (SMIK), kemudian SMKN 4 Padang yang dikenal dengan Sekolah Menengah Seni Rupa (SMSR), mempunyai beberapa program keahlian, diantaranya jurusan 
seni lukis, desain komunikasi visual, desain produk kriya tekstil, desain interior perhotelan dan landscaping, akuntansi, dan pemasaran serta SMKN 7 Padang yang masih dikenal dengan nama Sekolah Menengah Karawitan Indonesia (SMKI), menawarkan beberapa program keahlian diantaranya seni musik, seni tari, seni karawitan, seni teater, seni tata kecantikan dan teknik broadcasting. Tercatat pada tahun 1982 sebagai satu-satunya SMKI yang ada di Sumatera. Untuk Indonesia terdapat tujuh model sekolah yang sama seperti sekolah SMK ini, enam diantaranya terdapat di Bandung, Solo, Yogyakarta, Surabaya, Denpasar, dan Makasar (Padang, 2014).

Beragam keahlian yang dimiliki oleh setiap tamatan SMK seni, masingmasing jurusan memiliki keunggulan keahlian yang ditawarkan kepada setiap siswanya, setelah menempuh pendidikan dalam normalnya kurang lebih selama 3 tahun, setiap tamatannya memiliki keahlian tersendiri sesuai dengan bidang atau jurusan yang dipelajari. Keahlian yang dimiliki tersebut bisa langsung dipraktekkan dalam dunia kerja dan ada juga yang memilih untuk melanjutkan pendidikan ke perguruan tinggi seni yang tersebar diseluruh Indonesia. Sekolah Menengah Kejuruan (SMK) merupakan pendidikan yang memiliki kategori kelompok studi keahlian tertentu yang dipelajari melalui jurusan di sekolah kejuruan. Jurusan keahlian adalah spesialisasi ilmu dalam kelompok studi pada bidang keahlian tertentu (Tirtarahardja, 2005).

Ciri khas dari SMK-SMK berbasis seni ini, yaitu pelestarian seni etnik dan tradisi, khususnya ke-Minangkabauan, pengembangan yang inovatif harus dilakukan agar sekolah seni pertunjukan ini eksis dan diapresiasi oleh masyarakat, salah satunya melahirkan karya-karya seni, kerajinan tangan termasuk tari, musik dan karawitan. Sekolah ini mempunyai visi dan misi yang untuk mengedepankan kesenian pertunjukan dan kerajinan keMinangkabauan baik berskala lokal, nasional, maupun internasional.

Terdapat 35 Sekolah Menengah Kejuruan (SMK) di Sumatera Barat khususnya kota Padang, masing-masing SMK saling menonjolkan program keahlian yang ditawarkan pada siswanya (Fitria, 2009). Terdapat 3 SMK seni dan budaya berstatus negeri yang terletak di Kampus SMK Seni Budaya Kelurahan Cengkeh Kecamatan Lubuk Begalung Padang, 100 meter dari Jalan Raya Padang-Indarung yakninya SMKN 4, SMKN 8 dan SMKN 7, menjadikan SMK Negeri ini sebagai sekolah yang nyaman, sangat mudah dijangkau dan jauh dari kebisingan lalu lintas.

Ketiga sekolah kejuruan ini merupakan Sekolah Menengah Kejuruan (SMK) yang berbasis seni, seperti seni rupa, seni pertunjukan, dan seni media rekam. Ketiga SMK seni tersebut merupakan sekolah formal yang berbasis seni tradisional dan seni kerajinan di Sumatera Barat yang berada di kota Padang. 
Pertama, SMKN 8 Padang, keahlian yang ditawarkan adalah jurusan busana butik, teknik kendaraan ringan, teknik komputer jaringan, kriya keramik, kriya logam, kriya kayu, dan kriya tekstil, yang berasal dari nama Sekolah Menengah Industri Kerajinan (SMIK). Kedua, SMKN 4 Padang yang dikenal dengan Sekolah Menengah Seni Rupa (SMSR),mempunyai beberapa program keahlian, diantaranya jurusan seni lukis, desain komunikasi visual, desain produk kriya tekstil, desain interior perhotelan dan landscaping, akuntansi, dan pemasaran. Ketiga, SMKN 7 Padang merupakan salah satu SMK seni yang mengusung seni pertunjukan budaya Minang, masih tetap eksis dan besar dikenal dengan nama SMKI (Padang, 2014).

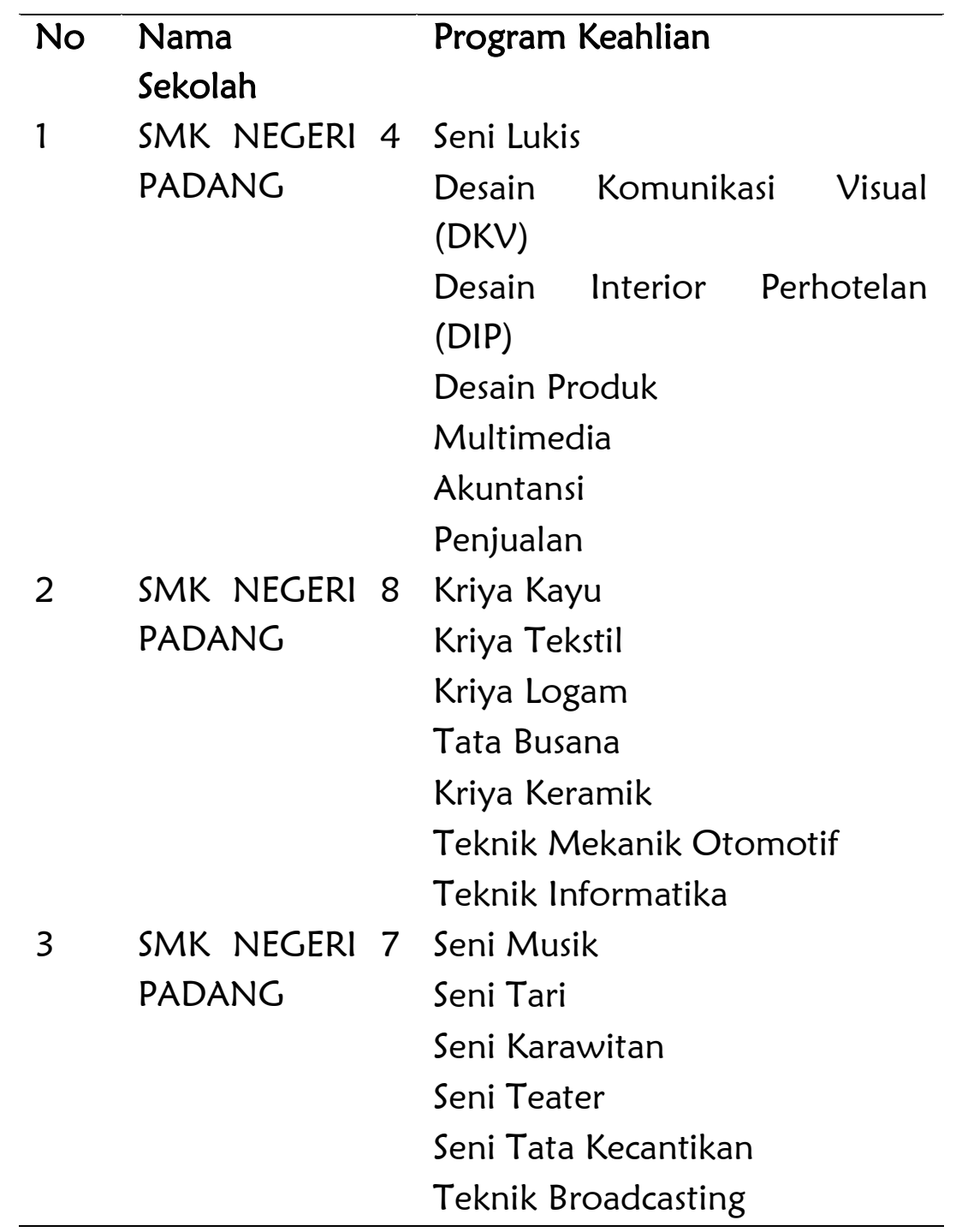

Tabel 1. Program Keahlian SMK Seni di Kota Padang Sumber: Diolah dari Profil SMKN Seni Budaya Kota Padang,

Dinas Pendidikan Kota Padang Tahun 2014 
Sri Haryati Putri

Sekolah Menengah Kesenian: Cipta Karakter Pelestari Budaya di Sumatera Barat

Tak dapat dipungkiri kehadiran lembaga pendidikan seni, satu diantaranya SSRI atau SMSR dan terakhir berganti nama lagi menjadi SMKN 4 Padang terbukti mampu memberikan kontribusi pada etalase seni rupa di tanah air dengan beragam pertumbuhan dan perkembangannya. SMKN 4 Padang merupakan salah satu sekolah seni budaya tertua di Sumatera dan cuma ada tiga di Indonesaia yang hingga kini telah berusia 50 tahun. Sekolah ini berdiri pada 25 September 1965. Dengan adanya sekolah ini maka dianggap sebagai cikal bakal atau embrio tumbuh dan berkembangnya seni rupa di tanah air.

Disusul kemudian kehadiran SMKN 8 Kota Padang yang dulunya bernama Sekolah Menengah Industri Kerajinan (SMIK) dengan ranah produk seni kerajinan yang berdiri di era tahun 1990-an, secara nyata turut memperkuat basis seni rupa dan kerajinan daerah sebagai bagian dari kebudayaan yang ada. SMK Negeri 8 Padang merupakan satu-satunya sekolah yang memiliki kompetensi kerajinan di Kota Padang yang menghasilkan berbagai macam produk kerajinan, fashion dan cinderamata dengan berbagai macam bahan dan keteknikan, terbuat dari logam, kayu, tekstil dan keramik. Banyaknya ragam hasil kesenian yang diciptakan oleh SMK-SMK seni budaya tidak hanya pada bidang seni rupa dan kerajinan tetapi juga dibidang seni bahasa dan sastra (Tumbidjo, n.d.).

Selanjutnya, Sekolah Menengah Kejuruan (SMK) Negeri 7 Padang merupakan satu-satunya sekolah menengah kejuruan di Sumatera Barat yang bergerak di bidang seni pertunjukan dengan etnis Minangkabau, dikenal dengan nama Sekolah Menengah Karawitan Indonesia (SMKI). Karawitan Minang merupakan ciri khas utama sekolah ini dalam mengusung setiap seni pertunjukan musik dan tarian tradisional. SMKN 7 Padang sebagai satusatunya SMK seni tradisi yang menjadikan karawitan Minang sebagai ciri khas sekolah dan digunakan sebagai materi dalam pembelajarannya, ditengah derasnya era globalisasi yang mengagung-agungkan modernitas, sekolah ini mampu mengusung kebudayaan lokal sebagai upaya untuk melestarikan ciri khas budaya suatu daerah, khususnya budaya Minangkabau.Kehidupan seharihari manusia baik disadariataupuntidak,tidakdapatlepasdari seni. Seni melekat pada hampir seluruh kehidupan manusia. Seni merupakan segala aktifitas manusia dengan pengalaman estetikanya yang dinyatakan dalam bentuk ekspresi pada media, gambar, suara dan gerak yang disusun sedemikian rupa sehingga bisa memberikan daya tarik dan keindahan.

Dalam arti pendidikan, seni bertujuan untuk mengembangkan kemampuan untuk mengapresiasi dan mengeskpresikan diri dengan berbagai medium seperti, seni rupa, bunyi, gerak, bahasa dan perpaduannya. Pendidikan seni memiliki peranan dalam pembentukan pribadi siswa yang 
harmonis dengan memperhatikan kebutuhan dan perkembangan anak didik untuk mencapai kecerdasan emosional dengan cara mempelajari salah satu bidang seni (Sedyawati, 2010).

Kehadiran SMK yang memiliki keahlian seni dan budaya daerah ditengah-tengah banyaknya sekolah kejuruan dengan beragam keahlian, merupakan suatu wadah yang dapat memudahkan para generasi muda kaum terpelajar yang terdidik terutama bagi para lulusan SMP untuk dapat melanjutkan pendidikan ke tingkat yang lebih tinggi sesuai dengan bakat seni yang telah dimiliki. Hal ini paralel dengan tujuan dan arti dari pendidikan seni yang hadir di permukaan sekolah formal, yaitu mempertahankan nilai-nilai kesenian tradisi Minangkabau ditengah terpaan kesenian Barat dan budaya Kpop yang dapat memudarkan seni musik tradisi dan budaya asli Minangkabau.

Oleh karena itu, lembaga-lembaga pendidikan yang bertujuan untuk melestarikan seni budaya bangsa perlu diselamatkan dan didukung (Navis, 1986). Semua pihak mesti mengapresiasi dengan adanya SMK-SMK seni ini, karena pendidikan seni budaya yang diterapkan oleh sekolah ini mampu menanamkan kembali rasa cinta kesenian dan tradisi Minangkabau pada kalangan generasi muda bangsa yang berguna untuk mendukung keunggulan Indonesia khususnya budaya Minangkabau di mata dunia. Pendidikan menengah kejuruan dengan basis kesenian, mempunyai dua visi yakni disamping untuk pelestarian budaya daerah, kesenian dan budaya yang dipelajari telah membekali siswa untuk mampu menjadikannya sebagai mata pencaharian.

Kegiatan tersebut merupakan aktifitas ekstrakurikuler luar sekolah yang dilakukan oleh para siswa-siswa jurusan seni. Jurusan seni tari, musik, karawitan laris manis dimanfaatkan masyarakat dan pemerintah Kota Padang dalam berbagai acara kesenian. Seperti, para siswa selalu diundang untuk tampil menari pasambahan, tari lilin dan tari piring dalam beragam seremonial acara formal. Begitupun dengan siswa jurusan musik, mereka juga selalu tampil dan diundang sebagai pengisi acara pada setiap acara kondangan masyarakat umum. Sebagai keuntungannya, mereka memperoleh tambahan uang belanja bahkan sebagian dari mereka di pergunakan untuk membiayai sekolahnya. Pada saat ini jarang sekali ditemukan orang-orang yang pandai dan cekapan dalam tarian dan kebudayaan Minang. Siswa sekolah yang ahli dalam kesenian Minang inilah yang kerapkali diberdayakan untuk menunjukkan kebolehan dalam pertunjukan kesenian Minangkabau.

Sebagai bagian dari kebudayaan, seni adalah salah satu perlengkapan manusia dalam memenuhi kebutuhannya. Tentunya kehidupan akan 
menjadi gersang tanpa kehadiran kesenian. Sepanjang sejarahnya seni memang mengabdikan diri untuk kemanusiaan. Tentunya, seni tradisi yang pada hakekatnya merupakan representasi dari kebudayaan luhur, sejak dulu telah menjadi media pendidikan yang ampuh dalam membentuk karakter masyarakatnya. Maka, sekolah yang menawarkan keahlian kesenian tradisi kepada siswanya patut untuk diapresiasi dan didukung penuh dalam perkembangan budaya lokal di setiap daerah. Kesenian tradisional pada umumnya mengandung nilai-nilai sosial yang dapat mencerminkan kebiasaan dari masyarakat, sehingga akan menjadi budaya dalam lingkungannya.

Namun, penanaman karakter dan moral yang cinta akan seni dan budaya tradisional, tidak begitu dengan mudahnya diterima dan diterapkan. Seni tradisional sekarang ini mulai redup dan jarang peminatnya. Pada situasi sekarang, keberadaan seni tradisi mulai kurang diminati oleh generasi muda, bahkan sudah hampir ditinggalkan. Mereka lebih menyukai budaya luar negeri yang dianggap lebih modernisasi. Apabila kondisi seperti ini tetap lestari, secara tidak sadar akan kehilangan jati diri sebagai bangsa yang memiliki identitas budaya daerah sendiri. Oleh sebab itu, perlu mengemas materi seni tradisi menjadi lebih kreatif dan inovasi, sesuai dengan perkembangan dan tuntutan zaman serta kebutuhan masyarakat, dengan catatan tetap berakar pada budaya asli seni tradisi sendiri (Wadiyo, 2008).

Oleh sebab itu, seni dan budaya tradisional yang diusung oleh SMKSMK seni patut untuk dilestarikan. Untuk melestarikan budaya tradisional agar dapat bertahan eksistensinya, maka harus ada hubungan kerjasama antara siswa dengan masyarakat dan antara guru dengan masyarakat dalam mengusung berbagai acara seni dan budaya Minangkabau (Wadiyo, 2008). Pendidikan karakter sangat membutuhkan peranan emosional (perasaan) yang salah satunya dapat diperoleh melalui pembelajaran dan pertunjukan seni. Sekolah-sekolah yang berbasis kesenian khususnya Sekolah Menengah Kejuruan (SMK) yang mengusung kesenian tradisi harus didukung oleh seluruh elemen kependidikan terutama pemerintah dan masyarakat agar budaya bangsa tidak terkikis oleh pengaruh budaya luar (Bahar, 2004).

Seni tradisi yang pada hakekatnya merupakan representasi dari kebudayaan luhur, sejak dulu telah menjadi media pendidikan yang ampuh dalam membentuk karakter masyarakatnya. Apresiasi dan dukungan penuh dalam perkembangan budaya lokal di setiap daerah sangat perlu dilakukan. Kesenian tradisional pada umumnya mengandung nilai-nilai sosial yang dapat mencerminkan kebiasaan dari masyarakat, sehingga akan menjadi budaya dalam lingkungannya. SMK-SMK seni wajib melaksanakan kegiatan pergelaran kesenian dengan tujuan disamping untuk meningkatkan kembali 
apresiasi masyarakat terhadap seni tradisi, juga bertujuan untuk memperkenalkan kekayaan seni budaya yang merupakan warisan nenek moyang supaya tetap lestari.

\section{Simpulan}

Perkembangan Sekolah Menengah Kejuruan (SMK), semakin hari kian menampakkan kemajuannya. Dimulai pada Repelita I hingga Repelita IV pemerintah terus menaruh perhatian penuh untuk memberikan anggaran yang besar kepada sekolah kejuruan. Hal ini tentu bertujuan untuk mendidik generasi bangsa yang terampil dibidang yang digeluti dan siap untuk memasuki dunia kerja secara profesional.

Oleh karena itu, mulai berkembang sekolah-sekolah kejuruan yang tersebar di seluruh Indonesia dengan beragam keahlian yang dimiliki oleh siswanya. Termasuk Sumatera Barat khususnya Kota Padang yang memiliki sekolah kejuruan berbasis seni tradisi Minangkabau. Terdapat tiga SMK seni, yakni SMKN 4 Padang, SMKN 8 Padang dan SMKN 7 Padang. Ketiga SMK ini merupakan sekolah kejuruan yang menawarkan seni budaya dan seni kerajinan Minangkabau kepada siswa tingkat menengah pertama yang ingin menekuni dunia seni.

Pemerintah Sumatera Barat dan seluruh stake holder dinas pendidikan dan kebudayaan, selalu berupaya membangun karakter generasi muda berbasis kearifan budaya lokal sejak dini, melalui jalur pendidikan dianggap sebagai langkah yang tepat. SMK-SMK seni budaya ini memiliki pegaruh dan peran penting dalam pembentukan karakter moral dan membentuk perilaku saling menghargai untuk berkompetisi dalam mengembangkan bakat seni yang dimiliki oleh siswa-siswanya. Penyelamatan dan aktualisasi terhadap bentuk-bentuk seni tradisi, seperti yang telah dilakukan oleh SMK-SMK seni ini, sudah sepatutnya untuk diapresiasi. Ditengah laju transformasi dan akulturasi budaya luar negeri, keberadaan seni tradisi masih tetap di minati oleh kalangan muda yang sadar akan budaya sendiri.

Sekolah seni inilah yang dapat dijadikan sebagai wadah dari lembaga formal sebagai pembentuk karakter yang cinta akan kearifan lokal, bangga terhadap budaya sendiri dan juga dapat ikut serta dalam pelestarian kesenian tradisional dan budaya daerah, serta yang terpenting NKRI selalu di hati, dengan seni kita merasa memiliki identitas sendiri, tanpa adanya akulturasi budaya akibat adanya westernisasi luar negeri. 
Sri Haryati Putri

Sekolah Menengah Kesenian: Cipta Karakter Pelestari Budaya di Sumatera Barat

\section{Daftar Rujukan}

Ahmad, Z. A. (1976). Memperkembang dan Mempertahankan Pendidikan Islam di Indonesia. Jakarta: Bulan Bintang.

Bahar, M. (2004). Seni Tradisi Menentang Perubahan, Bunga Rampai. Padang Panjang: STSI Padang Panjang.

Fitria, R. (2009). SMKN 3 Padang: Perkembangan Sekolah menengah Kejuruan di Kota Padang 1969-2007. Universitas Andalas.

Hasbullah. (2005). Dasar-Dasar Pendidikan. Jakarta: Raja Grafindo Persada.

Jazul., V. E. I. D. M. (2001). Mempertimbangkan Konsep Pendidikan Seni. Harmonia Jurnal Pengetahuan Dan Pemikiran Seni, 2 no. 2, 41.

Laporan Tahunan Kantor Wilayah Departemen Pendidikan dan Kebudayaan Provinsi Sumatera Barat Tahun 1979/1980. (2018). Padang.

Maryetti. (2010). Melestarikan Seni Tradisional Melalui Sekolah: SMK BISA" Jurnal Suluah Vol.10 No 13, Desember 2010. Hal 175. Jurnal Suluah, 10 No 13, 175.

Nasional, D. P. (2003). Kebijakan Departemen Pendidikan Nasional. Jakarta: Depdiknas.

Navis, A. A. (1986). Adat dan Kebudayaan Minangkabau. Padang.

Padang, D. pendidikan kota. (2014). Profil SMKNegeri Seni Budaya Kota Padang. Padang.

Purnawati., L. (2008). Pentingnya Pendidikan Seni Rupa Terhadap Perkembangan Otak Anak. Padang.

Sedyawati, E. (2010). Budaya Indonesia: Kajian arkeologi, seni, dan sejarah. jakarta: Divisi Buku Perguruan Tinggi, RajaGrafindo Persada.

Tirtarahardja, U. (2005). Pengantar Pendidikan. Jakarta: Rineka Cipta.

Tumbidjo, H. D. (n.d.). Minangkabau Dalam Seputar Seni Tradisional Jilid I. Padang: SSRI/SMSR Padang.

Wadiyo. (2008). Sosiologi. semarang: Universitas Negeri Semarang Press.

Yoeti, O. A. (1983). Pengantar ilmu pariwisata. Bandung: Angkasa. 